\title{
AN INVESTIGATIVE STUDY ON SUSTAINABLE COMPETITIVE ADVANTAGE OF MANUFACTURE COMPANIES IN INDONESIA
}

\author{
Edi PURWANTO ${ }^{\left({ }^{*}\right.}{ }^{*}$, Agnes Debora Bernice PURWANTO (®2 \\ ${ }^{1}$ Department of Management \& Jaya Launch Pad, Universitas Pembangunan Jaya, Tangerang Selatan, Indonesia \\ ${ }^{2}$ Department of Management, Universitas Bunda Mulia, Jakarta, Indonesia
}

Received 11 March 2020; accepted 3 August 2020

\begin{abstract}
The purpose of the research is to investigate the effect of external and internal factors on corporate performance and sustainable competitive advantage. The samples of the study are ten manufacturing companies in the pharmaceutical, cosmetic, and household utility sectors listed on the Indonesia Stock Exchange (IDX). The data analysis use PLS-SEM. The result shows that corporate performance is influenced by leverage and liquidity (internal factors) significantly but is not influenced by external factors significantly as well as organizational performance doesn't impact the sustainable competitive advantage significantly. The results of this study can be a concern for companies that corporate performance is not the ultimate goal of a business. Still, it must be followed by a sustainable competitive advantage if the company wants the return is not temporary, but sustainable. The originality of the paper is the results of this study show that the competitive advantage of an industry or company can not only rely on one factor, from external or internal environmental factors.
\end{abstract}

Keywords: macroeconomic, leverage, liquidity, firm performance, sustainable competitive advantage.

JEL Classification: E44, E52, G32.

\section{Introduction}

With confidence, Unilever Indonesia Ltd (UNVR) wrote on its website, "Every day, 2.5 billion people use various Unilever products... Therefore, this provides us with a good opportunity to build a brighter future" (Unilever, 2019). It also says, "Seven out of ten homes around the world use at least one Unilever product, and our world-leading household product brands including Lipton, Knorr, Dove, Ax, Hellmann's, and Omo" (Unilever, 2019). As one of the manufacturers of household goods sub-sector, UNVR is not just playing alone in the Indonesian and global markets. As reported by finance.detik.com, Unilever Indonesia Ltd, and Procter \& Gamble (P\&G) are often involved in tight price wars. Saputra (2013) mentions Procter \& Gamble Co. $(P \& G)$ as Unilever's eternal rival.

Procter \& Gamble Indonesia $(P \& G)$ has been serving Indonesian consumers for more than 30 years with trusted products such as Pantene, Head \& Shoulders, Rejoice, Downy, Gillette, Pampers, SK-II, Olay, and Vicks. As explained on the company's website, currently, P\&G Indonesia has become one of the key $P \& G$ global markets. Because $P \& G$ Indonesia, which has a factory in Kerawang, manufactures products for not only the local market but also global consumers. Hiring more than 500 high-skilled employees and thousands of employees in the distribution supply chain illustrates that $P \& G$ Indonesia not only has market opportunities but also has resource strength (PGcareers, 2019).

Unilever has since begun to operate in Indonesia and has succeeded in becoming one of the industry players with a leading business pace through 43 popular brands. In 2013 Unilever had eight factories that became its production base and claimed to have invested more than IDR 4 trillion in just the last three years. Unilever continues to try to maintain its market share from $P \& G$ because since $P \& G$ products have invaded Indonesia, $P \& G$ erode the Unilever market by $32 \%$. $P \& G$ has been tempting through its top brands such as Pantene, Rejoice, Head \& Shoulders, and Olay (Saputra, 2013).

Other companies that play and compete in the same industry. Namely, the manufacturing pharmaceuticals, cosmetics, and household utilities sectors listed on the Indonesia Stock Exchange include Akasha Wira International, Kino Indonesia, Mandom Indonesia, Darya Varia Laboratoria, Kimia Farma, Kalbe Farma, Merck Sharp

${ }^{*}$ Corresponding author. E-mail: edi.purwanto@upj.ac.id 
Dohme Pharma, Industri Jamu \& Farmasi Sido Muncul, Taisho Pharmaceutical Indonesia, Tempo Scan Pacific. Whereas P\&G Indonesia (PGIN) itself has delisted from the IDX since July 2004.

The Strategic Management study divides into two streams, namely the I/O Model and the RBV Model. I/O or Industrial Organization Models see the company's performance will highly depend on the opportunities of its external environment, namely the macro environment and the industrial environment or the competitive environment. Whereas the RBV or Resources Based, View Model considers that a company's performance will depend very much on the strength of the resources they have. But now experts in the field of strategic management, for example, Hitt et al. (2011) and David and David (2015), have agreed that the two factors cannot be separated. Company performance depends on opportunities and threats to the external environment as well as the strengths and weaknesses of resources or the company's internal environment. Based on the two strategic management models, it will examine how the influence of external factors (I/O Model) and internal factors (RBV Model) on the financial performance of manufacturing companies listed at the Indonesia Stock Exchange.

Egbunike and Okerekeoti (2018) has examined the external factors as having an impact on company performance, as well as the internal factors. The study is toward manufacturing companies in Nigeria. Macroeconomic or external factors that became the independent variables of the study include interest rates, inflation rates, currency exchange rates, and GDP growth. While the company's internal factors include company size, leverage, and liquidity. The company's return on assets (ROA) indicates the company's performance. Whereas Yadav et al. (2016) proved that external environmental factors not only have an impact on company performance but also lead to sustainable competitive advantage. The research objective is to investigate the effect of external factors, leverage and liquidity on firm performance, and the impact of firm performance on the sustainable competitive advantage of manufacturing companies in Indonesia. Therefore, the research questions are the following: First, how the effect of external factors on the performance of manufacturing companies? Second, how the impact of leverage on the performance of manufacturing companies? Third, how the impact of liquidity on the performance of the manufacturing company? And fourth, how the impact of company performance on the sustainable competitive advantage of manufacturing companies?

\section{Literature review}

\subsection{I/O Model}

The external environment becomes the primary determinant of the strategy chosen by the company to achieve success. The industrial organization (I/O) model of aboveaverage returns is the dominant factor of the external environment that influences various strategic actions of the company. The scale economy mainly determines the firm performance, multiple barriers to entering the market, diversification, product differentiation, and the level of concentration of the company in its industry (Hitt et al., 2011).

Economically, this I/O model has four underlying assumptions. First, the external environment provides various pressures and obstacles that determine the strategy and will produce above-average returns. Second, most companies compete in the same industry that uses almost the same resources by implementing a similar approach. Third, the resources used to implement the strategy are assumed to be able to move from one company to another, so that the differences in resources developed within companies in the same industry only apply to the short term. Fourth, corporate decision-makers are considered rational and committed to producing the best profit of the company compared to its competitors through profit-maximizing behavior (Hitt et al., 2011).

External factors such as politics, economics, socio-culture, technology, environmental sustainability issues, legal are macro factors that affect the performance of the company in the form of providing opportunities or threats. Likewise, technical factors such as the bargaining power of suppliers, buyers, newcomers, competitors, and substitute products are factors that influence company performance (F. R. David \& F. R. David, 2015).

\subsection{Resource-based view model}

The Resource-Based View Model assumes that each company is a collection of unique and capable resources. The uniqueness of the supply or capabilities owned by the company is the basis of the company's strategy and ability to get returns above the average. Resources are inputs in the production process of a company, such as capital equipment, individual skills of employees, patents, finance, and qualified managers (talented managers). Capability is the capacity that is within the company's resources to integrally to increase returns above average (Hitt et al., 2011). This RBV model considers that the competitive advantage of a company depends on internal resources that are unique, rare, costly to be imitated, and organized to be exploited. All of these are the essential factors for pursuing sustainable competitive advantage compared to external factors (F. R. David \& F. R. David, 2015).

From the RBV model perspective, the company's financial condition often considered as the only best measure for a company's competitive position and the attractiveness of investors to invest in the company. To know the strengths and weaknesses of investment, a company necessary to formulate strategies effectively. Liquidity, leverage, working capital, profitability, asset utilization, cash flow, and equity can be a company's strength in implementing the plan (F. R. David \& F. R. David, 2015). 


\subsection{Sustainable competitive advantage}

Strategic management studies recognize the external factors in the I/O model and internal factors in the RBV model are keys to create a competitive advantage and lead to sustainable competitive advantage. The industrial organization theories recognize external environments is keys to obtain a sustainable competitive advantage (Liou et al., 2015). Besides that, to create a sustainable competitive advantage, a company needs to have and develop unique, rare, costly to be imitated, and organized to be exploited. The company needs to develop them through cumulative experiences to create barriers to competitor replication. The company needs to develop them through know-how or expertise continues to develop new resources (Yadav et al., 2016).

\subsection{Previous studies}

Recent studies are needed to build gaps analysis. A gap analysis is assessment of previous studies for the purpose of identifying the defference between the previous studies and what this paper will investigate. Table 1 is the description of the previous studies.

Table 1. Previous studies

\begin{tabular}{|c|c|c|c|c|}
\hline No. & Author (year) & Research objective & Findings & Recommendation for future research \\
\hline 1 & $\begin{array}{l}\text { Vieira et al. } \\
(2019)\end{array}$ & $\begin{array}{l}\text { The purpose of the study is to analyze } \\
\text { the impact of the firm-specific (li- } \\
\text { quidity, leverage, firm size) and mac- } \\
\text { roeconomic factors (GDP, public debt, } \\
\text { investor sentiment, the existence of } \\
\text { managerial ownership, board size) on } \\
\text { Portuguese firms' performance (ROA). }\end{array}$ & $\begin{array}{l}\text { The study finds Liquidity, } \\
\text { leverage, GDP, Public debt, } \\
\text { Investor sentiment, the exis- } \\
\text { tence of managerial ownership } \\
\text { influence profitability, but } \\
\text { Firm size and board size do } \\
\text { not. }\end{array}$ & $\begin{array}{l}\text { Researchers give recommendations } \\
\text { for future research to investigate the } \\
\text { firm performance in other European } \\
\text { stock exchanges and include cost } \\
\text { efficiency and the firms' innovation as } \\
\text { determinants factors. }\end{array}$ \\
\hline 2 & $\begin{array}{l}\text { Egbunike and } \\
\text { Okerekeoti } \\
(2018)\end{array}$ & $\begin{array}{l}\text { The study aims are to investigate } \\
\text { the impact of macroeconomic } \\
\text { factors (interest rate and exchange } \\
\text { rate) and firm characteristics on } \\
\text { financial performance (ROA) among } \\
\text { manufacturing firms in Nigeria. }\end{array}$ & $\begin{array}{l}\text { The study finds interest rate } \\
\text { and exchange rate do not } \\
\text { influence performance, but } \\
\text { the inflation rate and GDP } \\
\text { influence firm performance. } \\
\text { The study also finds that firm } \\
\text { size, leverage, and liquidity } \\
\text { influence performance. }\end{array}$ & $\begin{array}{l}\text { The study gives managerial and } \\
\text { government policy implications but } \\
\text { did not provide recommendations for } \\
\text { future research. }\end{array}$ \\
\hline 3 & $\begin{array}{l}\text { Nanda and } \\
\text { Panda (2018) }\end{array}$ & $\begin{array}{l}\text { The purpose of the study is to } \\
\text { examine the impact of the firm- } \\
\text { specific (firm size, leverage, liquidity) } \\
\text { and macroeconomic (exchange rate) } \\
\text { on profitability (ROA and NPM) } \\
\text { among Indian manufacturing firms. }\end{array}$ & $\begin{array}{l}\text { The study finds the firm- } \\
\text { specific and Exchange rate } \\
\text { influences profitability. The } \\
\text { study finds the firm-specific } \\
\text { and Exchange rate influences } \\
\text { profitability. Size and liqui- } \\
\text { dity are essential factors to } \\
\text { enhances profitability, but } \\
\text { instead, leverage discourages } \\
\text { profitability. }\end{array}$ & $\begin{array}{l}\text { Researchers suggest to Exam indust- } \\
\text { rial factors may be an important de- } \\
\text { terminant of firm profitability for } \\
\text { future research. }\end{array}$ \\
\hline 4 & $\begin{array}{l}\text { Ndlovu and } \\
\text { Alagidede } \\
(2018)\end{array}$ & $\begin{array}{l}\text { The study purpose is to investigate } \\
\text { the impact macroeconomic (GDP, } \\
\text { interest rates, unemployment, and } \\
\text { exchange rates) on performance } \\
\text { (ROE) among BRICS financial } \\
\text { services firm. }\end{array}$ & $\begin{array}{l}\text { The study finds GDP and } \\
\text { interest rates influence ROE } \\
\text { positively, but unemployment } \\
\text { and exchange rates have a } \\
\text { negative influence. }\end{array}$ & $\begin{array}{l}\text { Researchers suggest investigating } \\
\text { the effect of operational efficiency, } \\
\text { funding structures, monetary policy, } \\
\text { and capital mobility on ROE and } \\
\text { other profitability measures for future } \\
\text { research. }\end{array}$ \\
\hline 5 & $\begin{array}{l}\text { Chowdhury } \\
\text { and Rasid } \\
(2017)\end{array}$ & $\begin{array}{l}\text { This study examined the impact of } \\
\text { Bank-specific (Credit risk, equity } \\
\text { financing, bank size, operating } \\
\text { efficiency, Liquidity management) } \\
\text { and macroeconomic (GDP, inflation, } \\
\text { money supply, Market capitalization, } \\
\text { oil price) on performance (ROA) } \\
\text { among the Islamic banks in Gulf } \\
\text { Cooperation Council (GCC) regions. }\end{array}$ & $\begin{array}{l}\text { The study finds that the } \\
\text { equity financing and bank } \\
\text { size positively influence pro- } \\
\text { fitability, but operating ef- } \\
\text { ficiency negatively and } \\
\text { significantly impact perfor- } \\
\text { mance. The study also finds } \\
\text { that money supply and inf- } \\
\text { lation adversely affect per- } \\
\text { formance substantially, but oil } \\
\text { prices positively influence it. }\end{array}$ & $\begin{array}{l}\text { Researchers recommend future } \\
\text { research to larger sample size and } \\
\text { extend the study by using other } \\
\text { performance measurements. }\end{array}$ \\
\hline 6 & $\begin{array}{l}\text { Dioha et al. } \\
(2018)\end{array}$ & $\begin{array}{l}\text { This study examined the impact of } \\
\text { firm characteristics (firm age, firm } \\
\text { size, sales growth, liquidity, and } \\
\text { leverage) on profitability (Return } \\
\text { on Sales) among consumer goods } \\
\text { companies in Nigeria. }\end{array}$ & $\begin{array}{l}\text { The study finds firm size, } \\
\text { sales growth, and leverage } \\
\text { influence profitability, but } \\
\text { firm age and liquidity are not. }\end{array}$ & $\begin{array}{l}\text { Researchers only give managerial } \\
\text { recommendations and not for future } \\
\text { research. }\end{array}$ \\
\hline
\end{tabular}


End of Table 1

\begin{tabular}{|c|c|c|c|c|}
\hline No. & Author (year) & Research objective & Findings & Recommendation for future research \\
\hline 7 & $\begin{array}{l}\text { Alarussi and } \\
\text { Alhaderi } \\
(2018)\end{array}$ & $\begin{array}{l}\text { This study examined the impact } \\
\text { firm size, working capital, company } \\
\text { efficiency, liquidity and leverage on } \\
\text { profitability in Malaysian listed } \\
\text { companies. }\end{array}$ & $\begin{array}{l}\text { The study finds firm size, } \\
\text { working capital, and com- } \\
\text { pany efficiency influence } \\
\text { profitability, but leverage has } \\
\text { a negative impact. And the } \\
\text { research finds liquidity does } \\
\text { not influence profitability. }\end{array}$ & $\begin{array}{l}\text { The recommendation for future } \\
\text { research is to include more factors and } \\
\text { conduct a comparative study between } \\
\text { companies in different countries. }\end{array}$ \\
\hline 8 & $\begin{array}{l}\text { Bist et al. } \\
(2017)\end{array}$ & $\begin{array}{l}\text { This study examined leverage, diver- } \\
\text { sification, size, liquidity, age, claim } \\
\text { payment, and premium growth on } \\
\text { performance (ROA) among insurance } \\
\text { companies in Nepal. }\end{array}$ & $\begin{array}{l}\text { The study finds that leverage, } \\
\text { premium growth, firm age } \\
\text { influence performance, but } \\
\text { premium growth, size, claim } \\
\text { payment, and liquidity has a } \\
\text { negative impact. }\end{array}$ & $\begin{array}{l}\text { Researchers do not recommend future } \\
\text { research. }\end{array}$ \\
\hline 9 & $\begin{array}{l}\text { Lasisi et al. } \\
\text { (2017) }\end{array}$ & $\begin{array}{l}\text { This study examined the impact of } \\
\text { leverage, liquidity, sales growth, and } \\
\text { operating expenses efficiency on } \\
\text { profitability (ROE) of agricultural } \\
\text { firms in Nigeria. }\end{array}$ & $\begin{array}{l}\text { The study finds that liquidity } \\
\text { and sales growth influence } \\
\text { profitability, but operating } \\
\text { expenses efficiency does not. } \\
\text { Leverage negatively influence } \\
\text { profitability. }\end{array}$ & $\begin{array}{l}\text { Researchers only give managerial } \\
\text { recommendations. }\end{array}$ \\
\hline 10 & $\begin{array}{l}\text { Ho and } \\
\text { Mohd-Raff } \\
\text { (2019) }\end{array}$ & $\begin{array}{l}\text { This study investigated the impact } \\
\text { of external fundamentals and in- } \\
\text { ternal characteristics (firm size, } \\
\text { financial distress, liquidity) on firm } \\
\text { performance among Shariah and } \\
\text { non-Shariah compliant firms. }\end{array}$ & $\begin{array}{l}\text { The study finds that external } \\
\text { fundamentals do not inf- } \\
\text { luence performance. The stu- } \\
\text { dy finds that firm size affects } \\
\text { the performance of Shariah } \\
\text { and non-Shariah compliant } \\
\text { firms. Financial distress } \\
\text { negatively influences the } \\
\text { performance of non-Shariah- } \\
\text { compliant firms, but not } \\
\text { for Shariah firms. Liquidity } \\
\text { influences the performance } \\
\text { of Shariah-compliant firms, } \\
\text { but not for non-Shariah- } \\
\text { compliant firms. }\end{array}$ & $\begin{array}{l}\text { Researchers' recommendation for } \\
\text { firms is to recognize the external and } \\
\text { internal factors as the key to firm } \\
\text { performance. And to acknowledge } \\
\text { the mechanisms is essential to sustain } \\
\text { performance for long-term survival. }\end{array}$ \\
\hline
\end{tabular}

\subsection{Gaps analysis}

In Table 1, Alarussi and Alhaderi (2018), recommended examining the impact of internal factors on firm performance as a comparative study between companies in different countries. Ndlovu and Alagidede (2018) investigated the effect of the external factors on firm performance, but the recommended to examine the impact of internal factors on firm performance for future research. Chowdhury and Rasid (2016), Nanda and Panda (2018), Vieira et al. (2019) recommended future research that investigates the impact of external and internal factors on firm performance still essential to be conducted in countries. Therefore, this study investigates the effect of external factors (Inflation, Exchange rate, and GDP Growth) and internal factors (leverage and liquidity) on firm performance.

In Table 1, Nanda and Panda (2018) investigate the determinants factor of performance (ROA and NPM). On the other hand, Ndlovu and Alagidede (2018) use ROE to measure performance. Then Ndlovu and Alagidede (2018) recommended using other performance measures for future research. Therefore, this study will use ROA, ROE, and NPM as proxies of firm performance.
As in Table 1, Ho and Mohd-Raff (2019) to investigate the impact of the external and internal factors on firm performance and to recognize that the mechanisms are essential to sustain performance for long-term survival, therefore this study following up on the recommendation. Maury (2018) stated that past performance and sustained market share influence the firms' sustainable competitive advantage (Maury, 2018). Likewise, Day et al. (1997), Nustini (2006) stated that profitability is the reward from past advantages, and firms need to sustain or enhance future advantages. So, Nustini (2006) conclude that the company that can control their performance will able to maintain its competitive advantage over its rivals.

\subsection{Hypotheses development}

\subsubsection{The effect of external factors on firm performance}

Firm performance is showed by profitability ratio (Liuspita \& Purwanto, 2019). Growe et al. (2014) found that the effectiveness of the external factors did not influence profitability, which profitability is proxy of company performance, especially in the banking sector in the United 
States. Still, several studies have verified the effect of the external factors on firm performance. Egbunike and Okerekeoti (2018) found external factors conditions were proven to have an impact on corporate financial performance. They said that external factors that were not under management's control included social environment, environmental issues, political conditions, government regulations, policies, suppliers, competitors. These factors affect company performance. Egbunike and Okerekeoti (2018) found the effect of interest rates, inflation rates, currency exchange rates, and GDP growth on the financial performance of consumer goods companies listed on the Nigerian Stock Exchange. Previously several other researchers, such as Mwangi and Wekesa (2017), tested the effect of external factors on the performance of companies in Kenya. Issah and Antwi (2017) also examined the role of external factors on the performance of companies in the U.K. Nanda, and Panda (2018) proved that although the exchange rate does not affect the profitability or performance of the company for the short term, for a long time, the effect demonstrated. Chowdhury and Rasid (2017) examined the impact of external factors on company performance, and they proved that inflation is a macroeconomic variable that affects profitability or company performance.

Then, Ndlovu and Alagidede (2018) also confirmed the influence of the external factors on company performance. They prove that GDP and interest rates, inflation, unemployment, and currency exchange rates affect Return on Equity (ROE) or profitability. Abaidoo (2019) also tested and proved that uncertain external factors policies cause corporate performance volumes. Vieira et al. (2019) also showed that external factors are a factor influencing the performance of non-financial companies in Portugal. Likewise, this research will test the following hypotheses:

H1: There is a significant effect of external factors on the performance of manufacturing companies.

\subsubsection{The effect of the leverage on the firm performance}

Nanda and Panda (2018) found that leverage discourages firm performance, especially in manufacturing companies in India. And Lasisi et al. (2017) found that leverage negatively influences firm performance. Likewise, Alarussi and Alhaderi (2018) found that leverage hurts firm performance, at least among companies in Malaysia.

Bist (2017) found that leverage is a vital factor in enhancing firm performance. Likewise, Dioha et al. (2018) found that leverage is an essential factor of firm performance among insurance companies in Nepal. As well as, Egbunike and Okerekeoti (2018) confirmed leverage is a significant factor for return on asset (firm performance). Also, Dioha et al. (2018) demonstrated leverage affect the profitability or performance of consumer goods sector companies in Nigeria. And Vieira et al. (2019) confirm also confirmed leverage is essential to increase firm performance.

Based on the research findings above, the following hypotheses formulation:
H2: There is a significant effect of leverage on the performance of manufacturing companies.

\subsubsection{The effect of the liquidity on the firm performance}

Bist et al. (2017) found that liquidity negatively influences firm performance. Dioha et al. (2018) found that liquidity is not a significant factor in firm performance. Alarussi and Alhaderi (2018) also found that liquidity is not an essential factor in firm performance. Then, Ho and Mohd-Raff (2019) found that liquidity influences firm performance of Shariah-compliant, but not for non-Shariah-compliant firms.

Lasisi et al. (2017) found that liquidity influences firm performance. Likewise, Nanda and Panda (2018) find that liquidity enhances firm performance. As well as Egbunike and Okerekeoti (2018) found that liquidity is an essential factor of return on asset (firm performance). Then, Dioha et al. (2018) demonstrated liquidity affect performance. And Vieira et al. (2019) confirmed liquidity is essential to increase firm performance.

Based on the research findings above, the following hypotheses formulation:

H3: There is a significant effect of liquidity on the performance of the manufacturing company.

\subsubsection{The effect of corporate performance on sustainable competitive advantage}

Ho and Mohd-Raff (2019) suggest about the essential to investigate the impact of the external and internal factors on firm performance and to sustain performance for long-term survival. Day et al. (1997), Nustini (2006) stated that performance is the reward from past advantages, so maintain performance is essential to enhance future advantages. Therefore, Maury (2018) called past performance is a vital factor in the sustainable competitive advantage. And Nustini (2006) conclude that the company has to control its performance to sustain its competitive advantage.

Tang and Liou (2010) provide 4 (four) proxies to explain the variables of sustainable competitive advantage with financial ratios, namely customer relationships, supplier relationships, intellectual property, and fixed asset management. Then Tang and Liou (2010) combine these ratios, which form a new proportion called DuPont Identity or known as ROIC (Return on Invested Capital). Yadav et al. (2016) prove that environmental resources enable companies with superior financial performance to maintain their competitive advantage. Lev and Gu (2016) state that company performance (ROA, ROE) determines a company's ability to maintain its competitive advantage. Based on the theory and research results above, the hypothesis formulation is as follows:

H4: There is a significant effect of company performance on the sustainable competitive advantage of manufacturing companies. 


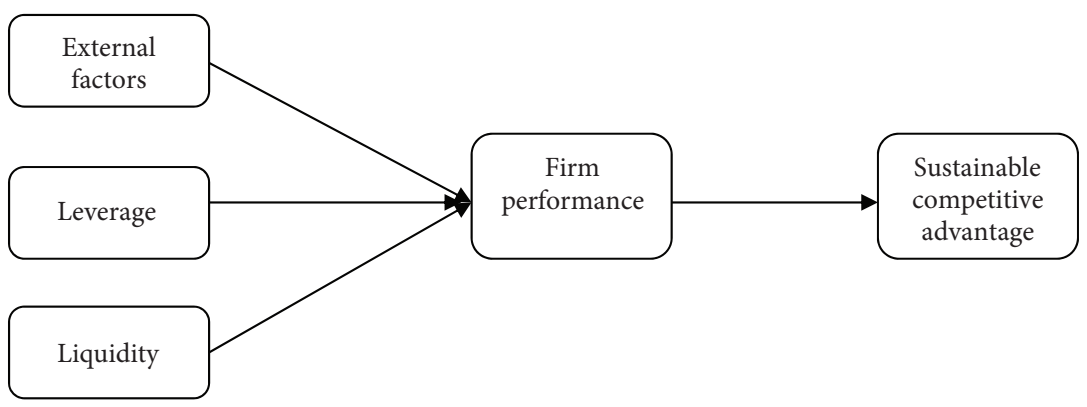

Figure 1. A Theoretical framework
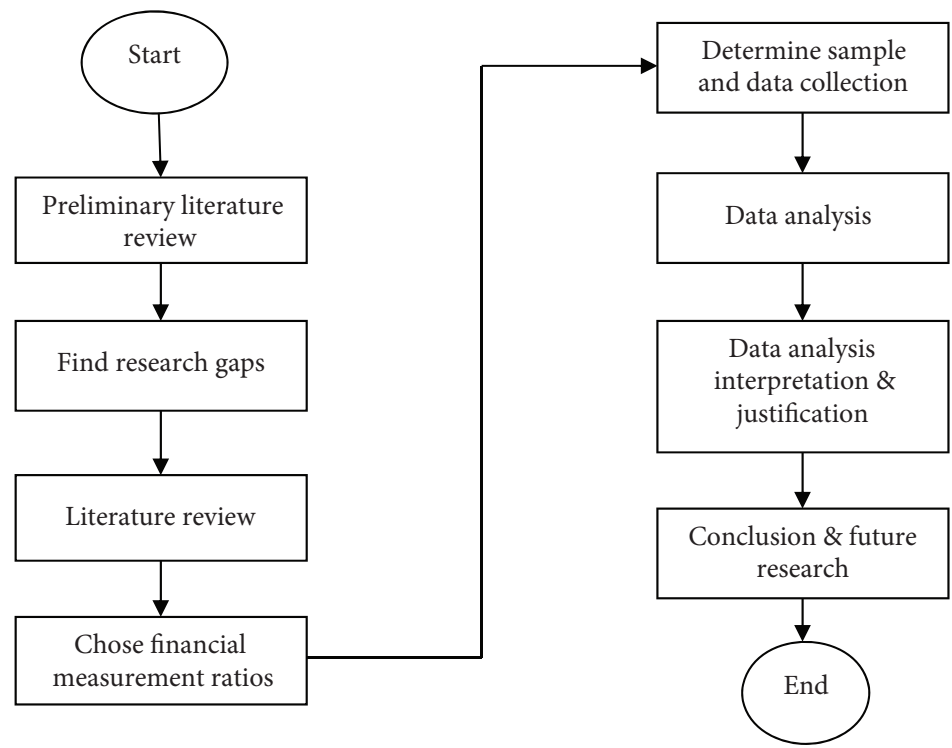

Figure 2. The research methodology (adapted from Lotfi et al., 2018; Mehrjerdi \& Lotfi, 2019)

\subsection{Research model}

Figure 1 is a theoretical framework base on above hypotheses.

\section{Methodology}

Figure 2 is the research methodology.

\subsection{Population and sample}

The population of the research is the manufacturing companies at the pharmaceutical, cosmetic, and household utility sectors listed on the IDX. This research uses secondary data. The study takes data sources from the company's financial statements of these companies. Akasha Wira International, Kino Indonesia, Mandom Indonesia, Unilever Indonesia, Darya Varia Laboratoria, Kimia Farma, Kalbe Farma, Merck Sharp Dohme Pharma, Industri Jamu \& Farmasi Sido Muncul, Taisho Pharmaceutical Indonesia, Tempo Scan Pacific, which can be accessed on IDX and also the company's website. The data taken is the financial statements for the period of 2015 to 2018 .

\subsection{Instrument development}

The independent variables of the research are macroeconomic, leverage, and liquidity, the intervening variable is corporate performance, and the dependent variable is a sustainable competitive advantage. The proxies of the external factors are inflation and exchange rate and GDP growth. The proxies of the leverage are Debt to Total Assets Ratio and Debt to Equity Ratio. The proxies of the liquidity are the Current Ratio, Quick Ratio, and Cash Ratio. The proxies of the corporate performance are Return on Asset (ROA, Return on Equity (ROE), and Net Profit Margin (NPM). According to Liou et al. (2015), return on invested capital (ROIC) represents the firm competitive advantage, and financial statements provide a good measurement of competitive advantage. Customer relationship, Supplier relationship, Intellectual property, Fixed asset management are sources of competitive advantage. See Table 2.

\subsection{Data analysis technique}

This research uses the Partial Least Squares-Structural Equation Modeling (PLS-SEM) technique. Structural Equation Modeling (SEM) is the second generation 
Table 2. Variables, proxies and formula/measurement

\begin{tabular}{|c|c|c|}
\hline Variables & Proxies & Formula/ Measurement \\
\hline $\begin{array}{l}\text { Sustain } \\
\text { Com- } \\
\text { petitive } \\
\text { Advan- } \\
\text { tage }\end{array}$ & $\begin{array}{l}\text { - Supplier relationship } \\
\text { - Fixed Assets } \\
\text { Management }\end{array}$ & $\begin{array}{l}\text { - Inventory turnover or } \\
\text { cost of sales/sales } \\
\text { - Fixed asset turnover } \\
\text { or depreciation/sales }\end{array}$ \\
\hline $\begin{array}{l}\text { Corporate } \\
\text { Perfor- } \\
\text { mance }\end{array}$ & $\begin{aligned} \text { - } & \text { Return on Asset } \\
& \text { (ROA) } \\
\text { - } & \text { Return on Equity } \\
& \text { (ROE) } \\
\text { - } & \text { Net Profit Margin } \\
& \text { (NPM) }\end{aligned}$ & $\begin{array}{l}\text { - Net income/total } \\
\text { assets } \\
\text { - Net income/total } \\
\text { equity } \\
\text { - Net profit/revenue }\end{array}$ \\
\hline $\begin{array}{l}\text { External } \\
\text { factors }\end{array}$ & $\begin{array}{l}\text { - Inflation } \\
\text { - Exchange rate } \\
\text { - GDP Growth }\end{array}$ & $\begin{array}{l}\text { - The annual change in } \\
\text { the CPI } \\
\text { - The official exchange } \\
\text { rate during a year } \\
\text { - The yearly change in } \\
\text { GDP }\end{array}$ \\
\hline Leverage & $\begin{array}{l}\text { - Debt to Total Assets } \\
\text { Ratio (DTAR) } \\
\text { - Debt to Equity Ratio } \\
\text { (DER) }\end{array}$ & $\begin{array}{l}\text { - Total debts/total assets } \\
\text { - Total liabilities/total } \\
\text { shareholders' equity }\end{array}$ \\
\hline Liquidity & $\begin{array}{l}\text { - Current Ratio } \\
\text { - Quick Ratio } \\
\text { - Cash Ratio }\end{array}$ & $\begin{array}{l}\text { - Current assets/current } \\
\text { liabilities } \\
\text { - Current assets - } \\
\text { inventory/ current } \\
\text { liabilities } \\
\text { - Cash + Cash } \\
\text { Equivalents/current } \\
\text { liability }\end{array}$ \\
\hline
\end{tabular}

method for analyzing multivariate data, which is generally tested and supports additional theoretical linear and causal models. Partial Least Squares (PLS) is software with a Structural Equation Modeling (SEM) approach using data distribution assumptions (Wong, 2013). Furthermore, Wiyono (2011) states that PLS is one SEM technique that can analyze latent variables, indicators, and measurements directly. According to Kock and Hadaya (2018), Structural Equation Modeling (SEM) is currently the quantitative analysis research technique of choice for industry and interdisciplinary researchers. Explosive growth among empirical researchers from various disciplines has occurred because the PLS-SEM measurement provides many available indicators and latent variables.

\section{Result and discussion}

\subsection{Measurement model (outer model)}

The outer model assessment involves testing individual indicators of reliability, internal consistency reliability, convergent, and discriminant validities (Hair et al., 2012; Dapas et al. 2019; Purwanto \& Budiman, 2020; Purwanto \& Loisa, 2020; Christian et al., 2020). Hair et al. (2012, p. 426) says that if the outer model testing has proven to be reliable and valid, then it can only be done testing the inner model. So it is clear that the external model assessment is a requirement for conducting an internal model assessment.
Hair et al. (2012), Purwanto (2016), Karno and Purwanto (2017), Tjiu and Purwanto (2017) said that the reliability indicator could be accepted when the value of standardized indicator loadings $\geq 0.70$. Table 3 indicates that the value of all outer loadings of each indicator is $>0.70$. Thus, all indicators proved reliable.

Table 3. Outer loadings

\begin{tabular}{|c|c|c|c|}
\hline Variables & Outer Loadings & Threshold point & Results \\
\hline \multicolumn{4}{|l|}{ Liquidity } \\
\hline Cash Ratio & 0.973056 & 0.70 & Valid \\
\hline Current Ratio & 0.985656 & 0.70 & Valid \\
\hline Quick Ratio & 0.996387 & 0.70 & Valid \\
\hline \multicolumn{4}{|l|}{ Leverage } \\
\hline $\begin{array}{l}\text { Debt to Asset } \\
\text { Ratio (DTAR) }\end{array}$ & 0.982454 & 0.70 & Valid \\
\hline $\begin{array}{l}\text { Debt to Equity } \\
\text { Ratio (DTER) }\end{array}$ & 0.988656 & 0.70 & Valid \\
\hline \multicolumn{4}{|l|}{ External factors } \\
\hline GDP Growth & 0.933968 & 0.70 & Valid \\
\hline Inflation & -0.715492 & 0.70 & Valid \\
\hline Exchange Rate & 0.903454 & & \\
\hline \multicolumn{4}{|c|}{ Firm Performance } \\
\hline ROA & 0.976484 & 0.70 & Valid \\
\hline ROE & 0.980770 & 0.70 & Valid \\
\hline NPM & 0.825266 & 0.70 & Valid \\
\hline \multicolumn{4}{|c|}{ Sustainable Competitive Advantage } \\
\hline $\begin{array}{l}\text { Fixed Asset } \\
\text { Turnover }\end{array}$ & 0.700006 & 0.70 & Valid \\
\hline $\begin{array}{l}\text { Inventory } \\
\text { Turnover }\end{array}$ & 0.804105 & 0.70 & Valid \\
\hline
\end{tabular}

According to Hair et al. (2012) to measure internal consistency reliability, do not use Cronbach's alpha value, but instead use composite reliability value. The composite reliability value must be $\geq 0.70$. Table 4 shows that the composite reliability value of all variables is $>0.70$, except for the macroeconomic amount, which is 0.611545 . However, according to Hair et al. (2011), in exploratory research, 0.60 to 0.70 is still acceptable. Thus it can be concluded that the composite reliability of all variables can be accepted or proven reliable.

Table 4. Composite reliability

\begin{tabular}{|l|c|c|l|}
\hline & $\begin{array}{c}\text { Composite } \\
\text { Reliability }\end{array}$ & $\begin{array}{c}\text { Threshold } \\
\text { point }\end{array}$ & \multicolumn{1}{|c|}{ Results } \\
\hline Macroeconomic & 0.611545 & $0.70^{*}$ & Reliable $^{\star}$ \\
\hline Leverage & 0.985455 & 0.70 & Reliable \\
\hline Liquidity & 0.989927 & 0.70 & Reliable \\
\hline Performance & 0.950465 & 0.70 & Reliable \\
\hline Sustainability & 0.722007 & 0.70 & Reliable \\
\hline
\end{tabular}

* According to Hair et al. (2011), the composite reliability value 0.60 to 0.70 is still acceptable. 
Convergent validity measured using the Average Variance Extracted (AVE) value and the AVE value must be $>\geq 0.50$. Table 5 shows that the AVE value of all variables is $>0.50$, so it the conclusion that the convergent validity value of all variables can be accepted or proven reliable.

Table 5. Average Variance Extracted (AVE)

\begin{tabular}{|l|c|c|c|}
\hline \multicolumn{1}{|c|}{ Variable } & AVE & $\begin{array}{c}\text { Threshold } \\
\text { point }\end{array}$ & Results \\
\hline External & 0.733485 & 0.50 & Valid \\
\hline Leverage & 0.971328 & 0.50 & Valid \\
\hline Liquidity & 0.970381 & 0.50 & Valid \\
\hline Performance & 0.865498 & 0.50 & Valid \\
\hline Sustainability & 0.566201 & 0.50 & Valid \\
\hline
\end{tabular}

\subsection{Evaluation of structural model (inner model)}

The inner model test results through bootstrapping show the level of significance of each hypothesis test, as can be seen in Table 6 .

Table 6 shows that the influence of external factors on corporate performance is not significant because its T-statistic value is $1.51<1.96$, but the effect of leverage on organizational performance is positive and significant because of its T-statistic value is $6.06>1.96$. Likewise, the impact of liquidity on corporate performance is significant because its T-statistic value was $2.26>1.96$. Still, the effect of the organizational performance on sustainable competitive advantage is not significant because its T-statistic value was $1.43<1.96$.

\subsection{Discussion}

Ireland and Hoskisson (2011) explain that sustainable competitive advantage will depend very much on how companies respond to various external factors and increase the strength or capability of company resources. That is, the sustainable competitive advantage does not only depend on external environmental factors or internal factors alone. Both have an essential role in improving company performance and sustainable competitive advantage.

The results of this study indicate that two hypotheses are significant, but the other two hypotheses are not significant. Internal company factors or company characteristics influence company performance, but external factors do not affect a significant on company performance. Although previous researchers have proved that external factors have a significant effect on corporate performance, this does not always occur because external factors are not the focus of companies. Issah and Antwi (2017), Chowdhury and Rasid (2017), Mwangi and Wekesa (2017), Egbunike and Okerekeoti (2018), Nanda and Panda (2018), Ndlovu and Alagidede (2018), Abaidoo (2019), Vieira et al. (2019) proved the proposition. But, Growe et al. (2014) found that in the U.S. banking sector, external factors did not significantly influence company performance. Likewise, the results of this research test, in which external factors consisting of inflation, GDP growth, and currency exchange rates did not affect the performance of several manufacturing companies.

Internal factors, including liquidity and leverage, have a significant effect on company performance, which is explained by return on assets, return on equity, and net profit margins. The findings of the proof of this hypothesis support the results of previous studies, such as the findings of Chowdhury and Rasid's (2016) research, Bist et al. (2017), Lasisi et al. (2017), Nanda and Panda (2018), Dioha et al. (2018), Alarussi and Alhaderi (2018) and Ho and Mohd-Raff (2019).

The key to sustainable competitive advantage is not only influenced by the company's performance. The company's performance is the result of the company's response to handling external factors and utilizing the capabilities of company resources (F. R. David \& F. R. David, 2015). It can be understood when the findings of this study do not prove that company performance has a significant effect on sustainable competitive advantage. That is because the company's performance itself only significantly influenced by internal company factors but not significantly influenced by external environmental factors.

\section{Conclusions and future research}

This study finds that the competitive advantage of an industry or company can not only rely on one factor, from external or internal environmental factors. This study also finds that the company's performance does not necessarily create the company's competitive advantage. The results show that: (1) the influence of external factors on company performance is not proved in this study. These results indicate that companies in the manufacturing industry

Table 6. Path coefficients (Mean, STDEV, T-Values)

\begin{tabular}{|l|c|c|c|c|c|c|}
\hline & $\begin{array}{c}\text { Original } \\
\text { Sample (O) }\end{array}$ & $\begin{array}{c}\text { Sample Mean } \\
(\mathrm{M})\end{array}$ & $\begin{array}{c}\text { Standard } \\
\text { Deviation } \\
(\text { STDEV) }\end{array}$ & $\begin{array}{c}\text { Standard Error } \\
\text { (STERR) }\end{array}$ & $\begin{array}{c}\text { T Statistics }(\mid \mathrm{O} / \\
\text { STERR } \mid)\end{array}$ & Result \\
\hline External -> Performance & 0.149300 & 0.152222 & 0.098558 & 0.098558 & 1.514850 & Rejected \\
\hline Leverage -> Performance & 0.731449 & 0.720577 & 0.120732 & 0.120732 & 6.058465 & Accepted \\
\hline Liquidity -> Performance & 0.362188 & 0.342985 & 0.160235 & 0.160235 & 2.260362 & Accepted \\
\hline $\begin{array}{l}\text { Performance -> } \\
\text { Sustainability }\end{array}$ & 0.338164 & 0.360031 & 0.236073 & 0.236073 & 1.432454 & Rejected \\
\hline
\end{tabular}


lack pay attention to the importance of responding to various shocks or changes in their external environment, such as GDP growth factors, inflation, and currency exchange rates. (2) The influence of leverage on company performance is proven to be positive and significant. These results indicate that the company has internal strength, and by utilizing the advantage of leverage can bring these companies to achieve company performance. Because these companies have inner strengths that can improve company performance, the company seems to pay less attention to external factors, as explained in the first conclusion above. (3) The effect of liquidity on company performance is also positive and significant. As with leverage, liquidity is an internal factor of the company. This study finds that the leverage of companies in this industry drive achievement of company performance. Liquidity is also a part of the internal factors that drive the success of company performance. And (4) the effect of company performance on sustainable competitive advantage is not proved significant. This study found that company performance has a mediating role to mediates the impact of external and internal environmental factors on sustainable competitive advantage. But in this case, the companies prioritize their inner strengths and pay less attention to external environmental factors. Therefore, so even though internal company factors create corporate performance, external factors received less attention, so company performance cannot encourage the creation of a sustainable competitive advantage.

Based on the conclusion above, the following are several research suggestions: (1) the results of this study can be a concern for companies both publicly listed companies and family companies that company performance is not the ultimate goal of a business. A sustainable competitive advantage must follow the company's performance if the company wants the company's performance is not temporary, but lasting. And the key to creating a sustainable competitive advantage is to improve company performance through strengthening the strength of the company's internal factors and the ability to respond and use the company's inner strength to overcome various threats and exploit the opportunities created by the company's external environmental factors.

The results of this study reinforce the belief of theoretical experts in the field of strategic management that the performance and competitive advantage of continuing an industry or company cannot only be oriented to one paradigm, for example, an industrial organization, or resources-based view. These two factors are essential, and together must be seen as a significant determinant of the performance and sustainability of a company's competitiveness. Thus it is recommended to further researchers to add external and internal factors to test other essential determinants in improving the performance and sustainability of the company's competitiveness.

Base on the conclusion, it is the recommendation for future research: First, examine the conceptual model to examine the determinants of firm performance and sustainability among outside manufacturing companies. Second, include other factors as interest rate, innovation, firm size, and age into the model. Third, conduct a comparative study to measure the impact of the factors on performance between companies with higher and lower performance.

\section{References}

Abaidoo, R. (2019). Corporate performance volatility and adverse macroeconomic conditions: A causal interaction perspective. Journal of Financial Economic Policy. https://doi.org/10.1108/JFEP-11-2018-0158

Alarussi, A., \& Alhaderi, S. (2018). Factors affecting profitability in Malaysia. Journal of Economic Studies, 45(3), 442-458. https://doi.org/10.1108/JES-05-2017-0124

Bist, J., Mali, R., SabitaPuri, Jha, R. K., Kayastha, S., \& Bhattarai, S. (2017). Impact of firm characteristics on the financial performance of insurance companies in Nepal. Osmania Journal of International Business Studies, 12(1), 1-11.

Chowdhury, M., \& Rasid, M. (2016). Determinants of performance of Islamic banks in GCC countries: dynamic GMM approach. In D. Mutum, M. Butt, \& M. Rashid, (Ed.), Advances in Islamic finance, marketing, and management (pp. 49-80). Emerald Group Publishing Limited. https://doi.org/10.1108/978-1-78635-899-820161005

Christian, M., Purwanto, E., \& Wibowo, S. (2020). Technostress creators on teaching performance of private universities in Jakarta during Covid-19 pandemic. Technology Reports of Kansai University, 62(06), 2799-2809.

Dapas, C. C., Sitorus, T., Purwanto, E., \& Ihalauw, J. J. O. I. (2019). The effect of service quality and website quality of Zalora.com on purchase decision as mediated by purchase intention. Quality - Access to Success, 20(169), 87-92.

David, F. R., \& David, F. R. (2015). Strategic management: concepts and cases (15th ed.). Pearson Education Limited, Edinburgh Gate.

Day, G. S., Reibstein, D. J., \& Gunther, R. E. (1997). Wharton on Dynamic Competitive strategy. John Wiley \& Sons, Inc.

Dioha, C., Mohammed, N. A., \& Okpanachi, J. (2018). Effect of firm characteristics on the profitability of listed consumer goods companies in Nigeria. Journal of Accounting, Finance, and Auditing Studies, 4(2), 14-31.

Egbunike, C. F., \& Okerekeoti, C. U. (2018). Macroeconomic factors, firm characteristics, and financial performance: A study of selected quoted manufacturing firms in Nigeria. Asian Journal of Accounting Research, 3(2), 142-168. https://doi.org/10.1108/AJAR-09-2018-0029

Growe, G., DeBruine, M., Lee, J., \& Tudón Maldonado, J. (2014). The profitability and performance measurement of U.S. regional banks using the predictive focus of the Fundamental Analysis Research. Advances in Management Accounting, 24, 189-237. https://doi.org/10.1108/S1474-787120140000024006

Hair, J. F., Ringle, C. M., \& Sarstedt, M. (2011). PLS-SEM: indeed a silver bullet. Journal of Marketing Theory and Practice, 19(2), 139-151. https://doi.org/10.2753/MTP1069-6679190202

Hair, J. F., Sarstedt, M., Ringle, C. M., \& Mena, J. A. (2012). An assessment of the use of partial least squares structural equation modeling in marketing research. Journal of the Academy of Marketing Science, 40(3), 414-433. https://doi.org/10.1007/s11747-011-0261-6 
Hitt, M. A., Ireland, R. D., \& Hoskisson, R. E. (2011). Strategic management concepts competitiveness \& globalization (9th ed.). South-Western Cengage Learning, Mason, Ohio.

Ho, C., \& Mohd-Raff, N. (2019). External and internal determinants of performances of Shariah and non-Shariah compliant firms. International Journal of Islamic and Middle Eastern Finance and Management, 12(2), 236-253. https://doi.org/10.1108/IMEFM-08-2017-0202

Issah, M., \& Antwi, S. (2017). Role of macroeconomic variables on firms' performance: evidence from the UK. Cogent Economics \& Finance, 5(1), 1-18. https://doi.org/10.1080/23322039.2017.1405581

Karno, C. G., \& Purwanto, E. (2017). The effect of cooperation and innovation on business performance. Quality - Access to Success, 18(158), 123-126.

Kock, N., \& Hadaya, P. (2018). Minimum sample size estimation in PLS-SEM: The inverse square root and gamma-exponential methods. Information Systems Journal, 28(1), 227-261. https://doi.org/10.1111/isj.12131

Lasisi, I. O., Dikki, C. A., \& Okpanachi, J. (2017). The empirical determinant of a firm's profitability: evidence from listed agricultural companies in Nigeria. Sahel Analyst: Journal of Management Sciences, 15(8), 66-88.

Liou, F.-M., Tang, Y.-C., \& Huang, C.-P. (2015). Asset-light business model: a theoretical framework for sustained competitive advantage. file://C:/Documents\%20and\%20Settings/ Administrator/My\%20Documents/Downloads/Asset-Light_ Business_Model_A_Theoretical_Framework\%20(1).pdf

Liuspita, J., \& Purwanto, E. (2019). The profitability determinants of food and beverages companies listed at the Indonesia stock exchange. International Journal of Scientific \& Technology Research, 8(9), 197-202.

Lotfi, R., Mostafaeipour, A., Mardani, N., \& Mardani, S. (2018). Investigation of wind farm location planning by considering budget constraints. International Journal of Sustainable Energy. https://doi.org/10.1080/14786451.2018.1437160

Maury, B. (2018). Sustainable competitive advantage and profitability persistence: Sources versus outcomes for assessing advantage. Journal of Business Research, 84, 100-113. https://doi.org/10.1016/j.jbusres.2017.10.051

Mehrjerdi, Y. Z., \& Lotfi, R. (2019). Development of a mathematical model for sustainable closed-loop supply chain with efficiency and resilience systematic framework. International Journal of Supply and Operations Management, 6(4), 360-388.

Mwangi, E. N., \& Wekesa, S. (2017). Influence of economic factors on organizational performance of airlines: a case study of Kenya Airways Ltd. IOSR Journal of Humanities and Social Science, 22(5), 8-14.

https://doi.org/10.9790/0837-2205050814
Nanda, S., \& Panda, A. K. (2018). The determinants of corporate profitability: an investigation of Indian manufacturing firms. International Journal of Emerging Markets, 13(1), 66-86. https://doi.org/10.1108/IJoEM-01-2017-0013

Ndlovu, C., \& Alagidede, P. (2018). Industry structure, macroeconomic fundamentals, and return on equity. International Journal of Emerging Markets, 13(6), 2047-2066. https://doi.org/10.1108/IJoEM-06-2017-0210

Nustini, Y. (2006). Determinants of sustainable competitive advantage due to an it-enabled strategy. Jurnal Siasat Bisnis, 11(1), 21-36. https://doi.org/10.20885/jsb.vol11.iss1.art2

Pgcareers. (2019). P\&G Indonesia. https://www.pgcareers.com/location-Indonesia

Purwanto, E. (2016). The effect of cosmopolitanism on perceived foreign product and purchase intentions: Indonesia case. Quality - Access to Success, 17(155), 94-98.

Purwanto, E., \& Loisa, J. (2020). The intention and use behaviour of the mobile banking system in Indonesia: UTAUT Model. Technology Reports of Kansai University, 62(06), 2757-2767.

Purwanto, E., \& Budiman, V. (2020). Applying the technology acceptance model to investigate the intention to use e-health: a conceptual framework. Technology Reports of Kansai University, 62(05), 2569-2580.

Saputra, S. M. (2013). UNILEVER VS P\&G: Persaingan Dagang Berlabel Lingkungan. https://ekonomi.bisnis.com/ $\mathrm{read} / 20130527 / 12 / 141332 /$ unilever-vs-pg-persaingan-dagang-berlabel-lingkungan

Tang, Y., \& Liou, F. (2010). Does firm performance reveal it's own causes? The role of Bayesian inference. Strategic Management Journal, 31, 39-57. https://doi.org/10.1002/smj.799

Tjiu, M., \& Purwanto, E. (2017). Guanxi and the leader-member exchange in the Chinese supervisor and subordinate relationship. Journal of Applied Economic Sciences, 12(8/54), 22182232.

Unilever. (2019). Tentang Unilever Indonesia. https://www.unilever.co.id/?navids=tcm:1310-50553-4

Vieira, E. S., Neves, M. E., \& Dias, A. G. (2019). Determinants of Portuguese firms' financial performance: panel data evidence. International Journal of Productivity and Performance Management, 68(7), 1323-1342. https://doi.org/10.1108/IJPPM-06-2018-0210

Wiyono, G. (2011). Merancang penelitian Bisnis dengan alat analisis SPSS 17.0 dan SmartPLS 2.0. UPP STIM YKPN.

Wong, K. K-K. (2013). Partial Least Squares Structural Equation Modeling (PLS-SEM) Techniques Using SmartPLS. Marketing Bulletin, 24.

Yadav, P. L., Han, S. H., \& Kim, H. (2016). Sustaining competitive advantage through corporate environmental performance. Business Strategy and the Environment, 26(3), 345-357. https://doi.org/10.1002/bse.1921 